\title{
UNEVEN DEVELOPMENT AND CAPITALIST PERIPHERALISATION: THE CASE OF IRELAND
}

PROINNSIAS BREATHNACH $\dagger$

\section{Introduction}

Spatial unevenness has been a consistent feature of capitalist development since its original rise to prominence in early modern Britain. This is not to say that uneven development is an exclusively capitalist phenomenon (nor, for that matter, that it is a necessary feature of capitalism - a question that will be discussed in the conclusion to this paper). Clearly, differences in levels of technology and geographical variation in natural resource endowments can give rise to variable levels of development, regardless of economic system - although geographers, and other social scientists, may have been inclined to overstress these factors, thereby providing an ideological smokescreen for more fundamental processes of uneven development under capitalism (Smith, 1984: 100). Certainly, nowadays, the distribution of natural resources has, at best, only a minor influence on the overall geography of capitalist investment and employment creation.

Apart from natural resource endowment, uneven development has occurred in the non-capitalist past through the transfer of surplus between social formations via plunder or enforced tribute exaction. This would normally have involved formations with no structural economic interlinkages, although there have been examples of structural reorganisation of regions by external forces for the purpose of systematic surplus extraction, as witness the introduction of slave-based commodity production into Western Europe by the Roman Empire (Anderson, 1978: 59-64).

Uneven development, however, reached its apotheosis with the 
emergence of capitalism as an integrated system of global dimensions. Under capitalism, uneven development has assumed a consistent structural configuration: the systematic exploitation by a set of dominant core regions of a corresponding set of peripheral dependent regions, the former therefore becoming centres of centripetal surplus accumulation and the latter sources of surplus extraction. However, while this basic conceptual model has tended to remain constant, the actual mechanisms of dominance and exploitation have changed over time, as has the detailed geography of cores and peripheries, with some former peripheries subsequently attaining core status, and vice versa. This reflects the remarkable adaptability of capitalism to changing historical circumstances.

In this paper, three major phases of capitalist core-periphery relations are identified, namely, mercantilism, the 'old' international division of labour and the more recent (and, as yet, incipient) 'new' international division of labour. The mechanisms of peripheralisation (i.e. the methods by which certain regions are reduced to, or maintained in, a subordinate or peripheral status by dominant core regions) associated with each phase are first briefly outlined. A detailed case study of Ireland, which has experienced all three forms of peripheralisation, is then presented to illustrate the functioning of these mechanisms. The paper concludes with a discussion of the role of uneven development within the overall functioning of the capitalist system.

\section{Capitalist peripheralisation: a periodisation}

The initial phase of capitalist core-periphery relations predated the full flowering of industrial capitalism, and revolved around the articulation, through the medium of merchant capitalists, of longdistance trading relationships between mainly non-capitalist producers, including petty commodity producers in England, other parts of Western Europe, and Northeast America, slave-based production elsewhere in the Americas, and communal and tribute-paying producers in Africa and Asia. This phase saw the subjugation of state policy to commercial interests (especially in England), as expressed in the emergence of mercantilism, where foreign - and particularly colonial - policy became devoted to the enrichment of the home country through external relationships and where political and military power were directed to the attainment of this objective, thereby initiating systematic domination and exploitation of overseas territories in the interests of 
the commercial classes at home (Regan;-1980: 6-7; Anderson, 1979: 35-7). Mercantilism sought, therefore, to create complementarity in the economic relations between colony and home country, with the colonies being diverted away from pursuing lines of production already established at home, and towards supplying products not produced at home (mainly for environmental reasons).

This incipient international division of labour became a centrepiece of the second phase of core - periphery relations under capitalism, following the industrial revolution in Britain and subsequently elsewhere. The competitive power of mass production now supplemented deliberate state policy in inhibiting and in some cases dismantling - industrial production in captive colonies. In place of the luxury consumer products (sugar, spices) which were emphasised in the mercantilist phase, colonies were now seen increasingly as sources of raw materials and foodstuffs for the factories and rising urban populations of the industrialising home countries. As Marx's celebrated quote put it: 'A new and international division of labour, a division suited to the requirements of the chief centres of modern industry springs u $\bar{p}$, and converts one part of the globe into a chiefly agricultural field of production, for supplying the other part which remains a chiefly industrial field' (Marx, 1961: 451). Of course, towards the end of the nineteenth century, minerals also became an important element of many peripheral economies.

In this second phase, colonial agricultural production remained, for the most part, non-capitalist in form, but articulated with the increasingly capitalist production systems of the home countries through unequal exchange relations which, $\bar{c}$ ombined with the considerable enhancement of the value of colonial raw materials through the manufacturing process, ensured that general standards of living in the colonial periphery fell far below those obtaining in the core regions.

The third - and present - phase of core-periphery relations has only come to prominence since the 1960s, and involves the increasing diffusion of capitalist relations of production to the periphery, albeit in subordinate form. This is achieved mainly via the medium of transnational investment (particularly in manufacturing industry), whereby industrial production in the periphery remains under the direct control of the core. The unequal trading relationship between capitalist and non-capitalist forms of production which characterised the second phase continues, but is now supplemented by direct appropriation of surplus value from wage labour across international boundaries. The emergence of 
this phase coincides with the virtual completion of the process of decolonisation of the Third World and the consequent spread of more indirect 'neo-colonial' mechanisms of exploitation of the periphery by the core. This phase sees a 'new' international division of labour emerging, whereby routine industrial production increasingly joins primary production as a peripheral activity, while the core regions increasingly specialise in high-level (and high-income) service functions such as administrative control, research and development and producer services, thereby preserving - and exacerbating - the income disparity between core and periphery (Fröbel et al., 1980; Massey, 1984; Peet, 1986).

This paper does not propose to examine the factors which accounted for the emergence of the original capitalist core areas or for subsequent rearrangements of the global core-periphery system. Rather, the main purpose of the paper is to illustrate the functioning of the three phases of core - periphery relations identified above in relation to Ireland - England's first colony - which, apart from a particular regional exception, has experienced all three forms of peripheralisation. The specific spatial forms which dependent peripheral development has taken in the Irish case will be outlined, and the case study will conclude by demonstrating how, although Ireland's peripheral status has remained unchanged, there has been a recent geographical shift in the core with respect to which this peripherality is defined, with the continental EEC 'heartland' increasingly occupying the position hitherto held by Britain.

\section{Phase 1: Mercantilism}

Prior to the initial rise of capitalism in England in the early modern period, Ireland's economy was essentially feudal in structure: Although clari-based, early medieval Gaelic society contained many feudal-type elements (Ó Corráin, 1972). There was some long-distance trade which was significantly expanded with the establishment of Viking settlements around the coast. Intermittent attempts to create a centralised 'high kingship' from the end of the tenth century probably reflect a general growth of surplus production. The incursion of a group of Anglo-Norman adventurers in the late twelfth century brought with it a more advanced form of feudal organisation. The superior military technology of this group allowed them to carve out substantial landholdings in the more fertile eastern and southern parts of the island. The Anglo-Normans subsequently became deeply gaelicised and, 
while in many cases they expressed nominatl loyalty to the King of England, as was generally typical of the feudal system, they functioned effectively as independent local magnates. To the extent that it existed at all, England's monarchical jurisdiction was confined to the restricted area around Dublin known as the 'Pale'.

Things changed fundamentally in the sixteenth century when, as part of the general centralising aspirations of the absolutist Tudor monarchy (Anderson, 1979: 113-142), the local power bases of Irish society were systematically broken down, a process that was complete by the end of the century. An added consideration here was the English fear, following the failure of the Irish nobility, both Gaelic and Anglo-Norman, to embrace the Protestant Reformation, of possible alliances between Ireland and Catholic powers on the European continent, especially Spain. As a means of pacifying the last bastion of Gaelic resistance - the northern province of Ulster - the land in this region was expropriated and transferred in substantial blocks to a variety of English and Scottish speculators who undertook to bring in settlers to occupy the land as tenant farmers. This augmented spontaneous settlement in the eastern part of the province emanating from nearby Scotland which had already taken place (Pringle, 1985: 98-104).

These Protestant settlers, for the most part, occupied the best land in the region, with the native Catholic population generally being displaced to the marginal areas where, nonetheless, they still had to pay rent to their new landlords. Thus was laid the foundation for long-lasting sectarian conflict in the province. The new settlers, originating for the most part from the denselypopulated lowlands of Scotland and England where commercial agriculture was already established, introduced a much more commercial orientation to their productive activities than had been the norm previously in feudal Ireland. This commercial orientation was subsequently extended to the remainder of the island following the general expropriation of Catholic landholders in the heel of the Cromwellian and Williamite Wars and the transfer of their land to a further wave of British speculative landlords. However, in this case, there was no accompanying plantation of settlers, so that the native Irish were kept on as rentpaying tenants. Thus, the proportion of Irish land owned by Catholics declined from $59 \%$ in 1641 to $14 \%$ in 1703 , and shrunk further to $5 \%$ by 1776 (Regan, 1980: 4-5).

The growing commercialisation of the Irish economy was greatly constrained by a series of mercantilist impositions by the English government in the second half of the seventeenth century. A 
series of Navigation Acts largely confined thê" carriage of Ireland's external trade to English ships and the mediation of English merchants. Despite its excellent position relative to international shipping movements, Ireland has never since developed a merchant naval tradition. A further series of acts in the 1660s, introduced at the instigation of English livestock producers who were feeling the effects of Irish competition, prohibited the export to England of cattle, sheep and pigs - the staple products of Irish agriculture. As a consequence, Irish agriculture became oriented towards the supply of provisions for the American colonial markets - markets which were much more unstable than the internal English market, giving rise to wild fluctuations in prices and recurrent crises for Irish producers (Regan, 1980: 7-8).

Perhaps the most far-reaching mercantilist measure of all, in terms of the future development of the Irish economy, was the 1699 Woollen Act, which effectively prohibited the export of woollen goods from Ireland, in the interests of the powerful English woollen lobby. Thus an emerging manufacturing sector which had been growing in tandem with its English counterpart was sent into sudden decline. Similar restrictions on the brewing, glass and sugar refining industries followed in the eighteenth century.

These measures set the course for the future development of the Irish economy, which henceforth was to act as a.specialist agricultural producer with little industrial development. The Irish economy was to come under the control of commercial farmers and associated merchants for whom there were few local industrial outlets for the reinvestment of profits. Accordingly, profits were invested in land and buildings in Ireland, or outside the island altogether in British industry and particularly in British government stocks. Irish capital, therefore, became concentrated among owners to whom risk-taking productive investments became increasingly alien - a situation which has changed little today, and which ensured that when such investment opportunities did become available subsequently when circumstances changed, they were rarely availed of (Regan, 1980: 8; Pringle, 1985: 122-6).

There was, however, one outstanding exception to this generalisation. The linen industry, thought to have been introduced into Ulster by Protestant refugees from mainland Europe, had no -direct competitor within England, and hence was allowed to develop unhindered. This it did at a rapid rate, to the extent that by 1800 , exports, at 38 million yards, were 76 times the level of a century previously (Regan, 1980: 8). Being still based on handcraft 
production, this rapid growth in output led to a diffusion of the industry from its point of origin in the northeast throughout much of rural Ireland, where it became a key element in the household income of smallholders and the growing numbers of cottiers (families occupying tiny plots for the production of subsistence crops) and landless labourers. The expansion of the linen industry indicates the extent to which mercantilism was oriented to serving narrow vested interests within the home country rather than representing a general policy of restricting development in the colonies.

\section{Phase 2: The 'old' international division of labour}

While the effect of the mercantilist phase was to orient the Irish economy towards agricultural specialisation (with the exception of the linen industry), it also forced Irish exporters to look beyond England for export markets, as the products of Irish agriculture were essentially the same as those of England, and were therefore excluded from the English market at the behest of English producers. However, as the pace of British industrialisation accelerated in the second half of the eighteenth century, rapid population and urban growth meant that domestic producers were increasingly unable to supply the demands of the food market, with the result that restrictions on imports from Ireland had to be relaxed: Accordingly, the Irish economy became increasingly locked into the British, as an exporter of agricultural products and importer of manufactured goods, in line with the classic international division of labour identified by Marx in the quotation cited earlier in this paper. Indeed, as Marx (1961: 711) himself noted, Ireland's 'true destiny' was 'that of an English sheep-walk and cattle-pasture.' Thus, by $1800,85 \%$ of Irish exports were destined for Britain, and $78 \%$ of imports were sourced therefrom, compared with figures of $46 \%$ and $54 \%$, respectively, for 1700 (Regan, 1980: 9-10).

Although, climatically, Ireland is not particularly suited to tillage, towards the end of the eighteenth century there was a gradual shift towards this form of agricultural production as a result of high prices and government bounties. This trend was accelerated by the outbreak of the Napoleonic wars, which required the feeding of large standing armies at a time when continental grain sources were cut off. The resultant increase in demand for farm labour underwrote a sudden surge in the Irish population growth rate: between 1781 and 1821 the total population rose from four millions to almost seven millions (Crotty, 
1986: 43). This increase consisted mainly of cottiers and landless labourers, whose sustenance became increasingly dependent on the extension of potato cultivation, mainly on tiny plots.

By 1800, therefore, the Irish economy had become characterised. by a much-bloated labour force heavily dependent on what was to prove an ephemeral export market. The dangers this situation presented, particularly to the most vulnerable sections of this labour force - the cottiers/labourers - became apparent after the cessation of the Napoleonic Wars in 1815, which ushered in industrial Britain's first sustained depression. Food (especially grain) prices fell drastically, and Irish farmers began to revert to the more traditional pastoral agriculture, with its low labour requirements. The deteriorating position of the Irish economy was further aggravated by the coming into full effect in the 1820 s of the economic provisions of the Act of Union of 1800, whereby Ireland was incorporated as an integral component of the United Kingdom. The free trade conditions which resulted from these provisions dealt a further blow to indigenous manufacturing industry (especially the cotton and woollen industries serving the home market), much of which was unable to withstand competition from its more technologically-advanced British counterparts.

The impending crisis was given further impetus by the rapid mechanisation of the linen industry from the late 1820 s onwards. This gave rise to spatial concentration in the Belfast region, thereby removing the second crutch upon which the rural underclasses depended. The latter became a true 'wretched of the earth', increasingly eking out a living from potato patches on common and marginal land, and increasingly vulnerable to recurrent attacks of blight on the potato crop. The momentum of population growth swamped the rising flow of emigration: by 1841 the total population had reached 8.5 millions. The complete failure of the potato crop in successive years in the late 1840 s produced results which were interpreted at the time as representing the 'natural' outcome of Malthusian population principles (Dunford and Perrons, 1983: 64-5). In fact, while nearly one million people died (mainly from disease) and another million emigrated in the space of five years, Irish commercial farmers continued to export large quantities of livestock and other food products to the British market. This phenomenon of the reorientation of agricultural production away from local needs to external markets was not, of course, unique to Ireland, but became a general feature of dependent peripheral economies. Similar disasters, for example, were a common occurrence in nineteenth-century India.

The population 'adjustment' engendered by the Irish Famine 
continued throughout the remainder 'of the nineteenth century when there was consistently heavy emigration, particularly from the western small-farm region. Thus, Ireland now became a supplier of cheap wage labour as well as a supplier of food to the industrial core (although much of the flow of labour was directed to the emerging core of the United States rather than to the established core of Britain). This flood of emigration also acted as a safety valve, assuaging the revolutionary potential of the underclasses of rural Ireland, a process which was further augmented by the transfer of outright land ownership to Ireland's tenant farmers in the late nineteenth and early twentieth centuries. The movement for land reform had originated among the small farmers in western Ireland, and initially sought quite radical objectives, including land redistribution. The movement was subsequently taken over by the large commercial farming interests, and its aims were reduced to seeking the transfer of existing holdings from tenancies to outright proprietorships. As a result, the eventual resolution of the land question did nothing to solve the economic problems of the bulk of Irish farmers, who continued to occupy tiny holdings, on which they produced young cattle for sale, via an unequal exchange relationship, to cattle dealers and cattle fatteners elsewhere. However, it did have the effect of creating a mass of conservative property-owning peasants who have dominated the Irish political scene until recently.

The second half of the nineteenth century saw the final parting of the way, in terms of economic structure, between Northeast Ireland and the remainder of the island. The mechanisation of the linen industry induced the establishment of a supplementary engineering industry which, in turn, attracted a major shipbuilding sector to the region. Belfast and the surrounding satellite towns, therefore, became a classic specialised urban-industrial region typical of the industrial revolution. In 1800, Belfast had a population of barely 20,000; by 1900 it had reached 350,000, by which stage it had surpassed Dublin (Pringle, 1985: 196-7). The Belfast region, therefore, had become an integral part of the British industrial core, in contradistinction to the remainder of Ireland (including much of Ulster), which remained firmly in the underdeveloped periphery.

\section{Interlude: Economic nationalism}

The late nineteenth century saw a significant rise in per capita incomes in rural Ireland, due to a combination of outmigration of 
underemployed labour, growing ảgricüultứfral prosperity, and a burgeoning flow of emigrants' remittances (Walsh, 1980a). This generated a corresponding growth in imports of British consumer goods, facilitated by the development of an extensive railway network. The possibility of supplying this growing market with indigenously-produced goods was not lost on certain elements within the native petty bourgeoisie, and became the principal plank of a new nationalist movement centred on the Sinn Féin ('We ourselves') organisation, founded in 1906. The upwelling of nationalist sentiment following the 1916 Rising produced a surge in political support for Sinn Féin. As had happened in the case of the land reform movement of the late nineteenth century, the commercial farmers and their merchant associates - whose need for British markets was at odds with Sinn Féin's protectionist policies - became involved in the independence movement in order to curb and dilute its more radical objectives. This broad front political alliance proved too strong for the British government to resist; however, for the industrial northeast (for whom access to the markets of Britain and its colonies was of essential importance) Sinn Féin's policies of economic nationalism were anathema and were resisted fiercely. This created the basis for partition, with the 26 southern counties attaining independence in 1922, with the remaining six northern counties remaining within the United Kingdom.

As was to happen frequently in subsequent cases of decolonisation elsewhere, the temporary broad front alliance which had been formed in the south split almost immediately upon the attainment of independence. The faction which assumed power represented mainly the commercial farming and mercantile interests, a classic comprador bourgeoisie whose main concern was the creation of stable conditions for the resumption of normal trading relations with Britain. Representing the dominant economic interests in the new state, the new government placed the emphasis on agricultural development, and made only token gestures towards the Sinn Féin policies of industrialisation via protectionism.

However, the onset of international depression in the early 1930s provided the opportunity for the other main faction to gain power and implement the original Sinn Féin policy of economic nationalism. This faction reflected the interests of the (largely embryonic) 'national' bourgeoisie, but was able to gain political power by enunciating populist policies in favour of the small farmers and urban working class. Tariff barriers were erected to provide protection for incipient home-based manufacturers, and 
laws were passed to ensure that the fatter would be Irish-owned and controlled. Initially, this policy met with some success: manufacturing employment (which accounted for less than $10 \%$ of the workforce in the south at the time of partition) grew by $50 \%$ between 1926 and 1951.

However, further progress on the road to indigenous industrialisation quickly fell foul of a number of obstacles which may be seen as the inheritance of the colonial legacy (Walsh, 1980b). Low general incomes and a small and still declining population (less than three millions in 1951) prevented the attainment of the economies of scale which might have facilitated the subsequent penetration of export markets, as had happened with other countries which had initially industrialised behind protective barriers. Besides reducing the overall population, emigration selectively removed the most enterprising members of the population: to quote Oldham's (1914: 213-4) memorable phrase, 'there had been, in Ireland, a perpetual survival of the unfittest, a steady debasement of the human currency ...' The spurt of industrial growth in the 1930s and 1940s did not reflect a widespread spirit of innovative enterprise among the new national bourgeoisie; rather, it represented the risk-free exploitation of guaranteed markets in basic consumer goods made available by protective legislation. Once these markets had been satisfied, further industrial investment ground to a virtual halt.

But perhaps the most fundamental constraint of all on indigenous industrial development deriving from the colonial heritage was the continuing concentration of the country's capital assets in the hands of the ultra-conservative agricultural and mercantile elite, to whom risk-taking investment was anathema (Lee, 1969). Most of these assets were invested in foreign banks and government stocks; indeed, foreign investments by Irish nationals greatly exceeded Ireland's total national income. Mobilisation of these assets - as had happened in Germany in the late nineteenth century - could have financed the successful pursuit of independent development; however, for all its overt populist radicalism, Eamonn de Valera's ruling Fianna Fáil party was not prepared to tackle Ireland's propertied establishment.

Ireland's rather tentative attempt at economic autarky, therefore, ran out of steam in the 1950s. At a time when the rest of Europe was booming, the Irish economy stagnated. Relative to the size of the base population, the emigration rate reached unprecedented levels. The deepening crisis required new economic departures. Proposals to base further industrial growth on large-scale processing of foodstuffs by state enterprise were 


\section{UNEVEN DEVELOPMENT AND CAPITALIST PERIPHERALISATION 133}

rejected by an almost totally " cónësërvativive political system. Instead, the decision was made to re-engage Ireland fully in the international capitalist system.

\section{Phase 3: The 'new' international division of labour}

In the late 1950s, the Irish government embarked on a new economic development policy which represented a direct reversal of the protectionism of the previous quarter century. Henceforth, the objective was to be the creation of an export-oriented industrial base through the attraction of foreign investment. Generous tax concessions and capital grants were to be the main formal incentives to be offered to outside firms, along with plentiful and relatively cheap labour (at a time when labour elsewhere in Western Europe was becoming scarce and expensive). An energetic promotion agency, the Industrial Development Authority, was entrusted with the task of securing appropriate industrial projects from external sources.

The new policy gradually gathered momentum through the 1960 s, and when Ireland joined the EEC in 1973, there was a marked acceleration of inward investment, as transnational companies sought to exploit Ireland's position as a low-cost base for supplying the EEC market (Telesis Consultancy Group, 1982: 135). By 1984, some 850 foreign firms had located in Ireland, representing a total investment of IR $f 7.5$ billions and employing 80,000 workers - over one third of all manufacturing employment (Industrial Development Authority, 1985a). Indeed, foreign firms accounted for the entire growth (34\%) in manufacturing employment between 1961 and 1981. Expansion in indigenous manufacturing employment had been stymied by a major shakeout among those indigenous firms which had been established during the protectionist period due to their inability to withstand outside competition in the new free trade conditions they had to face in the recessionary mid-1970s. The United States has been by far the leading source of foreign investment in Ireland, accounting for almost $40 \%$ of plants, over $40 \%$ of employment and over $50 \%$ of investment. The United Kingdom and West Germany are the other leading sources, but there is also a wide range of investments, mainly from Western Europe, Japan and Canada.

The new foreign plants are mainly concentrated in expanding, high-technology sectors (such as electronics, engineering and pharmaceuticals) in contrast with the traditional firms (mainly engaged in textiles, footwear, and clothing) which they replaced. 
Not only are they much larger, on avêrage, than indigenous plants, but they are also much more productive and exportoriented: while accounting for one third of manufacturing employment, they contribute one half of manufacturing output and $80 \%$ of non-food manufacturing exports (Industrial Development Authority, 1985b). Foreign firms, in fact, export over $90 \%$ of their Irish output, thus fulfilling the Irish government's objective of using such firms to create an export-oriented industrial base. On the other hand, foreign firms also import over $80 \%$ of their material inputs, thus confirming that they are using Ireland as a classic export platform, with very limited linkages with the domestic economy.

The failure of foreign firms to develop supply linkages with indigenous firms has been ascribed in some quarters to deficiencies within the indigenous industrial sector (Telesis Consultancy Group, 1982: 118-20). At the same time, it is clear that a major factor in favour of maintaining external backward and forward linkages is the facility this provides for manipulating intracorporate transfer prices in order to fully exploit Ireland's tax concessions. Thus, foreign firms whose operations are verticallyintegrated find it in their interests to import their inputs at artificially low prices and export their output at inflated prices, in order to concentrate their profits in Ireland (Murphy, 1984; $\mathrm{O}^{\prime}$ Leary, 1984). The extent to which foreign firms based in Ireland trade with affiliate companies abroad is already well documented. McAleese (1977: $36-7$ ) shows that three quarters of foreign firms in Ireland trade with overseas affiliates, to whom they send $68 \%$ of their exports, and from whom they obtain some $40 \%$ of their imports. Of U.S. firms, $85 \%$ trade with overseas affiliates, which account for $86 \%$ of their exports and over $50 \%$ of their imports.

The existence of a considerable level of transfer price manipulation on the part of foreign firms located in Ireland is attested to by their high level of profitability (although some of this may also be attributed to other favourable aspects of the Irish operating environment). Thus, in 1983, the profits of foreign firms as a proportion of sales were 16.5 times higher than those of indigenous Irish firms (Industrial Development Authority, 1985b). For U.S. firms - those most likely to be involved in transfer price manipulation - the ratio was 22:1. In 1983, American subsidiaries located in Ireland reported a rate of return on investment of $24 \%$ - six times the overall average for U.S. subsidiaries in the EEC (Sunday Tribune, November 4, 1984, quoting the U.S. Department of Commerce's Survey of Current Business).

Given their major contribution to Ireland's external trade; 
foreign firms have, by understating the value of imports and overstating that of exports, produced an unprecedented surplus in Ireland's visible trade balance in recent years. Counterbalancing this, however, has been an accelerating flow of profit repatriation from Ireland - up from IR $£ 228 \mathrm{M}$ in 1979 to IR $£ 1,360 \mathrm{M}$ (the equivalent of $8.4 \%$ of total GNP) in 1986 . In the earlier years of foreign investment in Ireland, foreign firms reinvested a high proportion of profits locally, as they built up their operations to target levels. In recent years, however, up to $80 \%$ of the profits of foreign firms have been repatriated (Industrial Development Authority, 1985b).

When foreign investment inflows were running at a high level in the 1970s and employment was rising, the Irish government was quite happy with the direct employment created by foreign firms. In the 1980s, however, with new investment falling back considerably, unemployment rising (to average levels of almost $20 \%$ in the late eighties, despite a resumption in net emigration), and increasing strains being placed on the domestic economy by the need to service a burgeoning foreign debt (equal to $60 \%$ of GNP at the end of 1987) there has been growing concern about the lack of domestic economic spin-offs from foreign investment. Apart from the high level of profit repatriation (which means that surplus generated in Ireland - even if much of it is artificial - is reinvested to create economic growth elsewhere), the main deficiencies of foreign firms in Ireland are neatly summarised in the following passage from a major review of Irish industrial policy commissioned by the Irish government:

Foreign-owned industrial operations in Ireland with few exceptions do not embody the key competitive activities of the businesses in which they participate; do not employ significant numbers of skilled workers; and are not significantly integrated into traded and skilled subsupply industries in Ireland. (Telesis Consultancy Group, 1982: 151)

In other words, apart from having a low level of material linkages with the indigenous economy, foreign manufacturing plants located in Ireland are mainly involved in low-skill assembly and testing operations with minimal research and development, little independent marketing capacity, and limited decision-making administrative functions. Such a profile clearly places Ireland in the dependent periphery within the 'new' international division of labour which has emerged since the 1960s. By specialising in 
production functions - both primäry ânind secondary - where average income levels are lower, Ireland is consigned to an economic status which is permanently inferior to that of the core areas of economic power which increasingly specialise in highlevel tertiary activities and which receive the highest levels of remuneration. Given the absence of the latter activities, Ireland's ability ever to close the gap with the core regions is rendered increasingly difficult.

An important aspect of Ireland's position in the new international division of labour has been a shift in the core with respect to which Ireland's peripheral status is defined. The creation, and subsequent enlargement, of the EEC has led to the gradual emergence of a coherent core-periphery structure within - Western Europe focussed on the so-called 'Golden Triangle' linking, roughly, Brussels, Stuttgart and Hamburg. As one moves out from this central core, there is a gradual growth of both geographical and economic peripherality. Other regions with a similar relative location to Ireland's (such as Southern Italy and Portugal) have also been experiencing a similar transition from a - specialisation in primary production and emigration to dependent industrialisation, although the specific form which this has taken has varied from case to case (Lewis and Williams, 1981; Dunford, 1986).

The evolution of this West European core-periphery structure has been accompanied by an increasing interpenetration of national capitals within the core region and the emergence of truly multinational corporate entities (in terms of ownership and control). This is a development of major historical significance, as it marks a fundamental departure from the previous tendency for capitalist corporations to have particular national affiliations and to be subject to particular national politicial influences. The impending creation of a 'Single European (i.e. EEC) Market' by 1992 could accelerate the movement towards eventual West European political union; accordingly, the current pattern of nation-states (which tends to hinder the process of international capitalist integration) may not be as rigid as has sometimes been suggested (e.g. Smith, 1984: 143-4).

The reorientation of Ireland's external economic links towards

- the new multinational European core has been greatly accelerated by the recent economic decline of Britain, which had previously monopolised these links. In 1924, 98\% of Irish exports went to, and $80 \%$ of imports came from, the United Kingdom. By 1964, the corresponding figures were $71 \%$ and $51 \%$, respectively. In 1986 , the UK accounted for only $34 \%$ of Irish exports and $42 \%$ of 
imports, by which time the remainder of the EEC received $38 \%$ of Irish exports and generated $26 \%$ of imports. The reorientation of the Irish economy to serve the EEC heartland has been accompanied by a deterioration of Ireland's economic position relative to that heartland, as has been the general experience of the EEC's peripheral regions (Keeble et al., 1982). Thus, between 1973 and 1979, Ireland's GDP per capita (measured in purchasing power parities) fell from $65 \%$ to $61 \%$ of the EEC average (Foley and Walbridge, 1981). Were it not for EEC financial assistance (in 1979 , net payments of grants and subsidies - mainly agricultural - amounted to almost 7\% of Ireland's GNP), the relative position would have been much worse.

\section{The role of spatial unevenness in capitalist development}

The foregoing case study has illustrated the changing nature of the process of uneven development within the capitalist system. While the nature of the links between core and periphery has evolved, as has the geography of the core-periphery structure, the core-periphery system itself has continued (Wallerstein, 1979). This raises the question as to how central such a system is to the fundamental functioning of capitalism. Marx, of course, was a firm believer in an inherent tendency towards equalisation within capitalism, and appeared to extend this belief to the spatial dimension, as suggested by his expectation that, in time, India would evolve into an independent capitalist power (Smith, 1984: 94). While the latter expectation remains far from realisation, the emergence of alternative centres of capitalist power in the previously underdeveloped Asian periphery (Taiwan, South Korea) provides some evidence in support of the equalisation tendency.

At the same time, the tendency for the development gap between cores and peripheries to widen (as in the case of Ireland vis-a-vis the European core, outlined above) appears to be much more in evidence today. Smith (1984) has argued that capitalism requires the constant production and reproduction of uneven development, in order to periodically reinvigorate the process of , capital accumulation through the provision of outlets for highprofit investment. Across-the-board equalisation, he argues, would involve a general reduction in profit levels, chronic stagnation in the accumulation process, and potentially terminal crisis. Smith, therefore, proposes a 'see-saw' model of uneven development, whereby capital moves from highly-developed 
regions of low profitability tõ less-developed regions of high profitability which, eventually, will culminate in a reversal of roles between these categories of regions and a reversal of capital flows in a future time period. Thus, regions will find themselves being systematically developed and underdeveloped in rotation.

Smith's scenario appears to indicate a cyclical pattern of investment and disinvestment, which suggests a possible correspondence with Kondratiev long waves of capitalist development. However, these latter are not the rhythmic cycles of a stable system, but a system undergoing continuous long-term expansion (albeit experiencing recurrent short-term setbacks). Each successive long wave portrays progressively more sophisticated - forms of technology and business organisation which, in turn, produce new and coherent spatial patterns of investment which depart significantly - if not fundamentally - from anything that has gone before. There would appear to be little historical evidence (in the era of industrial capitalism) of the 'see-saw' pattern of development postulated by Smith, which suggests a tendency for investment to switch backwards and forwards between two sets of regions.

Rather, the historical trajectory being followed by capitalist development would seem to involve a gradual deepening of capitalism on a global scale, with capitalist social relations progressively penetrating all areas and aspects of everyday living (with the possible exception of some social formations where socialism is being built). Smith (1984: 139) himself has eloquently acknowledged this trend:

The world market based on exchange is transformed into a world economy based on production and the universality of wage labour. Spatial integration through the price mechanisms of the commercial market ... is increasingly infiltrated and replaced at a more fundamental level by spatial integration through the law of value.

While Rosa Luxemburg expected that capitalism would not survive without having non-capitalist societies to exploit (Smith, 1984: 95), the universalisation of the capitalist mode of production does not presage either the collapse of capitalism or the spatial equalisation of capitalist development. The expansion of capitalism is associated with a continuing process of concentration of ownership and control of the means of production and exchange in the form of giant transnational corporate entities, which 
become fewer and fewer with the ongoing operation of the mechanisms of takeover and merger. With this concentration of control in the hands of a contracting number of dominant corporations, a small number of urban centres wherein the headquarters functions of these corporations are located have emerged as the effective core regions of modern capitalism (Cohen, 1981; Hymer, 1972). These 'global cities' account for only a tiny proportion of the total number of people incorporated either directly or indirectly - into the increasingly integrated world capitalist system, but include in their populations the recipients of the highest personal incomes in that system, in the form of top-level corporate functionaries and associated providers of business and sociocultural services.

With the increasing integration of capitalism on a worldwide scale, we are witnessing the evolution of a truly global central place system, with a coherent international central place hierarchy through which information is assembled and distributed, and through which decisions are filtered downwards and surplus is extracted upwards. This is essentially a more complex and sophisticated version of the metropolis/satellite structure identified over two decades ago by Frank (1969: 3-17). Whereas conventional functionalist geographers have tended to portray the central place system as involving a symbiotic relationship between town and countryside, the scenario depicted here sees central places as devices to facilitate control and exploitation.

In this scenario, spatially uneven development would appear to be an essential ingredient of capitalist development. However, in social terms, it may be that, apart from an elite minority involved in control functions at various levels in the hierarchy, the tendency will be towards equalisation. As technological change reduces the skill levels of most production and service workers and broadens the range of locations within which their work can be done, and as capitalist relations embrace a growing proportion of the world's workers, whether in urban or rural areas, a general levelling out of wages may be in prospect.

In the case of Ireland, the diffusion of capitalist production has generated very significant increases in absolute living standards, while deindustrialisation elsewhere has reduced living standards, as unemployment has grown and workers' bargaining powers have been attenuated. Nevertheless, Irish living standards have yet to reach those which still prevail in the deindustrialised regions of advanced economies, and while a trend towards convergence is in evidence, it is doubtful whether the logic of capitalism would allow Ireland (or any other region experiencing a 
similar form of development) to surpass the latter regions, which are increasingly making themselves available for the same kind of branch-plant industrialisation. What is clear, however, is that regions like Ireland have no prospect, given the current processes of uneven development, of ever closing the gap between themselves and the dominant core regions of international capitalism.

\section{References}

Anderson, P. (1978) Passages from Antiquity to Feudalism. London: New Left Review Verso Editions.

Anderson, P. (1979) Lineages of the Absolutist State. London: New Left Review Verso Editions.

Cohen, R. B. (1981) The new international division of labour, multinational corporations and urban hierarchy. In M. Dear and A. J. Scott, (Eds.) Urbanization and Urban Planning in Capitalist Society. London: Methuen, pp. $287-315$.

Crotty, R. (1986) Ireland in Crisis. Dingle: Brandon Book Publishers.

Dunford, M. (1986) Integration and unequal development: the case of southern Italy. In A. J. Scott and M. Storper, (Eds.) Production, Work, Territory. London: Allen and Unwin, pp. 225-45.

Dunford, M. and D. Perrons (1983) The Arena of Capital. London: Macmillan.

Foley, A. and P. Walbridge (1981) The socio-economic position of Ireland within the European Economic Community. National Economic and Social Council Report No. 58. Dublin: The Stationery Office.

Frank, A. G. (1969) Latin America: Underdevelopment or Revolution? New York: Monthly Review Press.

Fröbel, F., J. Heinrichs and O. Kreye (1980) The New International Division of Labour. Cambridge: Cambridge University Press.

Hymer, S. (1972) The multinational corporation and the law of uneven development. In J. Bhagwati (Ed) Economics and World Order from the 1970s to the 1990s. London: Collier-Macmillan, pp. 113-140.

Industrial Development Authority (1985a) Ireland: The Location for Successful Business. Dublin.

Industrial Development Authority (1985b) The Irish Economy Expenditures of the Irish Manufacturing Sector. Dublin.

Keeble, D., P. L. Owens and C. Thompson (1982) Regional accessibility and economic potential in the European Community. Regional Studies 16: 419-32.

Lee, J. (1969) Capital in the Irish economy. In L. M. Cullen (Ed) The Formation of the Irish Economy. Cork: Mercier Press, pp. 53-63.

Lewis, J. and A. M. Williams (1981) Regional uneven development in the European periphery: the case of Portugal. Tijdschrift voor Economische en Sociale Geografie 72: 81-98.

McAleese, D. (1977) A Profile of Grant-Aided Industry in Ireland. Dublin: The Industrial Development Authority.

Marx, K. (1961) Capital. Moscow: Foreign Languages Publishing House, Vol. 1. Massey, D. (1984) Spatial Divisions of Labour. London: Macmillan.

Murphy, A. (1984) How the bureaucrats 'lost' $£ 500$ million. Sunday Tribune, June 6: 8 .

Ó Corráin, D. (1972) Ireland before the Normans. Dublin: Gill and Macmillan. 
Oldham, C. H. (1914) The incidence of emigration on rown and country life in Ireland. Journal of the Social and Statistical Inquiry Society of Ireland XIII: 207-18.

O'Leary, J. (1984) Some implications of the revisions of the balance of payments and the national accounts. The Irish Banking Review September 1984: 13-34.

Peet, R. (1986) Industrial devolution and the crisis of international capitalism. Antipode 18: 78-95.

Pringle, D. G. (1985) One Island, Two Nations? Letchworth: Research Studies Press.

Regan, C. (1980) Economic development in Ireland: the historical dimension. Antipode 12 (1): 1-14.

Smith, N. (1984) Uneven Development. Oxford: Basil Blackwell.

Telesis Consultancy Group (1982) A Review of Industrial Policy. Dublin: National Economic and Social Council Report No. 64.

Wallerstein, I. (1979) The Capitalist World-Economy. Cambridge: Cambridge University Press.

Walsh, F. (1980a) Irish economic development 1905-1959. Paper to Conference on 'Irish Economic Development: Historical and Contemporary Views', University College, Cork.

Walsh, F. (1980b) The structure of neo-colonialism: the case of the Irish Republic. Antipode 12 (1): 66-72. 